\title{
Dermatomycosis among Elementary School Children in Jatinangor West Java
}

\author{
Isni Maulina Sukmara ${ }^{1}$, Risa Miliawati ${ }^{2}$, Hadyana Sukandar ${ }^{3}$ \\ ${ }^{1}$ Faculty of Medicine Universitas Padjadjaran, ${ }^{2}$ Department of Dermatology and Venerology \\ Faculty of Medicine Universitas Padjadjaran/Dr. Hasan Sadikin General Hospital, ${ }^{3}$ Department of \\ Epidemiology and Biostatistics Faculty of Medicine Universitas Padjadjaran
}

\begin{abstract}
Background: Dermatomycosis often occurs in tropical countries. Many studies from tropical countries have reported high prevalence of dermatomycosis among elementary school children. Despite being a tropical country, prevalence of dermatomycosis among elementary school children in Indonesia is still unknown. The objective of this study was to determine the prevalence and characteristics of dermatomycosis among elementary school children in Jatinangor, Sumedang, West Java in September-November 2012.

Methods: This study used a cross-sectional descriptive survey method. The 328 children from five elementary schools in Jatinangor were included in the study using multistage sampling technique. Medical history and physical examination was performed to all subjects. Subjects who had skin lesion suspected for dermatomycosis were examined with direct microscopic examination using $10 \%$ solutions of potassium hydroxide (KOH). Data were presented as frequent analysis distribution using Statistical Package for Social Sciences (SPSS) version 17.0.

Results: Of 328 children (174 males, 154 females; aged 5-14 years), 35 (10.6\%) had lesions suggestive of dermatomycosis but only 5 children $(1.5 \%)$ were positive for dermatomycosis. Males are more prevalent than females, patients were in $\geq 10$ years age group. Four cases were Pityriasis versicolor, while one was diagnosed with tinea facialis.

Conclusions: Dermatomycosis among elementary school children in Jatinangor had a low prevalence, with only 4 cases of Pityriasis versicolor and one tinea facialis case. [AMJ.2015;2(1):268-75]
\end{abstract}

Keywords: Dermatomycosis, elementary school children, prevalence

\section{Introduction}

Dermatological infection is a disease which occurs within all classes of society, and yet gains little attention because it is considered as unthreatening and negligible. Many factors influence the event of dermatological infection. The World Health Organization (WHO) epidemiology study about dermatological infection in children living in developing countries stated that several important factors can increase the risk of dermatological disease such as low hygiene, difficult access to clean water, climate factor, and population density. One of the dermatological infections which is promoted by hot and humid climate (tropical) is the superficial mycosis. ${ }^{1}$

Dermatomycosis is widely reported in many studies around the world. The results showed that dermatomycosis affects $20-25 \%$ of the world's population. ${ }^{2}$ A research in Nigeria $^{3}$ reported that $67 \%$ of the 82 dermatological cases found in a clinic was caused by fungi and the most afflicted age group is between 10-40 years old. Dermatomycosis research on elementary school children is also widely conducted and showed a quite high prevalence, such as the research in Dar Es Salam $^{4}$, the research showed that out of 420 children being studied, 241 of them or $57.3 \%$ are afflicted by dermatological diseases. From all dermatological conditions found, dermatomycosis have a prevalence of $20 \%$ (84/420) with dermatophytosis as the most common type at $11.4 \%(48 / 420)$.

Despite being a tropical country, the study about dermatomycosis among elementary school children in Indonesia is still limited. Jatinangor, West Java was chosen as the study area to see the prevalence of dermatomycosis among elementary school children in one of the regions in Indonesia.

Correspondence: Isni Maulina Sukmara, Faculty of Medicine, Universitas Padjadjaran, Jalan Raya Bandung-Sumedang Km.21, Jatinangor, Sumedang, Indonesia, Phone: +6285624179080 Email: isnimaulina@gmail.com 


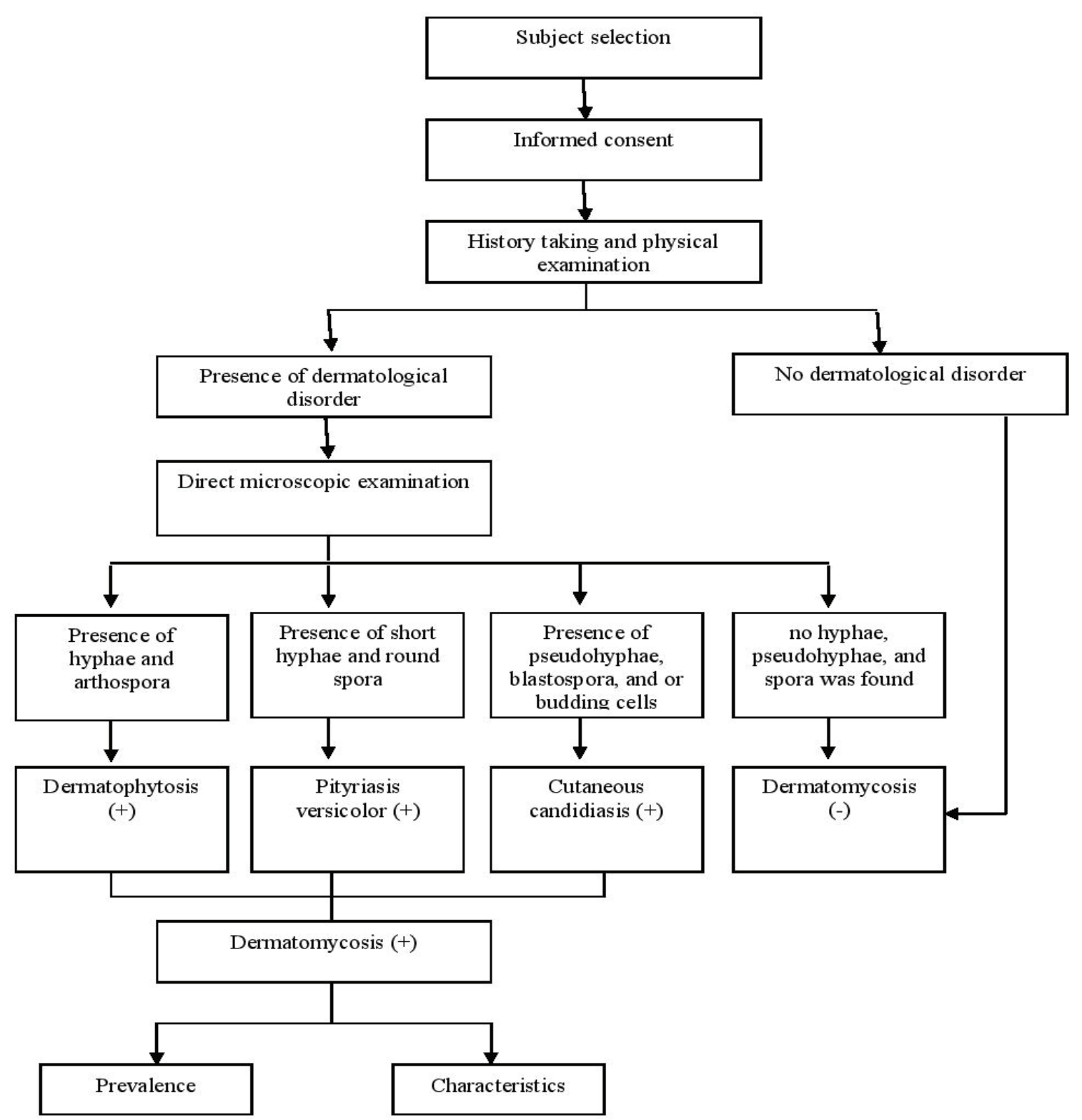

Figure 1 Flow of Research Procedure

\section{Methods}

This cross-sectional descriptive surveillance study was performed in public elementary schools (Sekolah Dasar Negeri;SDN): SDN Cileles, SDN Jatiroke I, SDN Jatinangor, SDN Paripurna, and SDN Sirahcai, Jatinangor, Sumedang District, West Java. The study was conducted between September-November 2012. This study had been studied and approved by the Health Research Ethic Committee, Faculty of Medicine, Universitas Padjadjaran.

Three hundred and twenty eight children from a total of 8,462 elementary school children in Jatinangor were chosen using multistage sampling method and simple random sampling method. The randomization started from village units of the 12 villages in Jatinangor to randomly choose five villages. 
Table 1 Research Subject Characteristics

\begin{tabular}{|c|c|c|}
\hline Characteristics & $\mathbf{n}$ & Percentage (\%) \\
\hline \multicolumn{3}{|l|}{ Age } \\
\hline$<10$ & 196 & 59.8 \\
\hline$\geq 10$ & 132 & 40.2 \\
\hline \multicolumn{3}{|l|}{ Gender } \\
\hline Male & 174 & 53 \\
\hline Female & 154 & 47 \\
\hline \multicolumn{3}{|l|}{ Body Mass Index } \\
\hline Very low & 19 & 5.8 \\
\hline Low & 58 & 17.7 \\
\hline Normal & 226 & 68.9 \\
\hline Overweight & 14 & 4.3 \\
\hline Obesity & 11 & 3.4 \\
\hline \multicolumn{3}{|l|}{ Frequency of bathing } \\
\hline$<2$ times a day & 12 & 3.7 \\
\hline 2 times a day & 306 & 93.3 \\
\hline$>2$ times a day & 10 & 3 \\
\hline \multicolumn{3}{|l|}{ Towel Usage } \\
\hline Shared & 46 & 14 \\
\hline Not Shared & 282 & 86 \\
\hline \multicolumn{3}{|l|}{ Wearing of Head Cover } \\
\hline Yes & 101 & 30.8 \\
\hline No & 227 & 69.2 \\
\hline \multicolumn{3}{|l|}{ Layered Clothing } \\
\hline Yes & 154 & 47 \\
\hline No & 174 & 53 \\
\hline \multicolumn{3}{|l|}{ Sharing of Clothing } \\
\hline Yes & 36 & 11 \\
\hline No & 292 & 89 \\
\hline \multicolumn{3}{|l|}{ Habit of playing with dirt } \\
\hline Yes & 101 & 30.8 \\
\hline No & 227 & 69.2 \\
\hline \multicolumn{3}{|l|}{ Pets } \\
\hline Yes & 95 & 29 \\
\hline 1 type & 71 & 74.7 \\
\hline 2 types & 24 & 25.3 \\
\hline None & 233 & 71 \\
\hline \multicolumn{3}{|l|}{ History of personal skin diseases } \\
\hline Present & 51 & 15.5 \\
\hline None & 277 & 84.5 \\
\hline
\end{tabular}




\begin{tabular}{lcc}
\hline \multicolumn{1}{r}{ Characteristics } & n & \\
& & Percentage (\%) \\
\hline $\begin{array}{l}\text { History of familial skin diseases } \\
\text { Present }\end{array}$ & 1 & 0.3 \\
None & 327 & 99.7 \\
Immunocompromised condition & & \\
Present & 2 & 0.6 \\
None & 326 & 99.4 \\
\hline
\end{tabular}

The next randomization is in the scope of the elementary school in each village to be studied. After five elementary schools were chosen, randomization was furthered into the smaller scope of which children should be chosen. An inclusion criterion was all elementary school students who are present on the day of examination. Permission, in the form of a signed informed consent from parents or guardian, was obtained before the students were included in the research. An exclusion criterion was the absence of children at the day of examination.

In this study, subject history form was filled, and physical examination by a medical doctor was performed. Direct microscopic examination to support the diagnosis of dermatomycosis was conducted so the prevalence and characteristics of the patients such as age, gender, risk factor body mass index (BMI), frequency of bathing, towel usage, head cover wear, habit to wear layered clothings or to share clothings, habit to play with soils, the ownership of pets, history of dermatological disease both on self and in the family, and immunocompromise condition) and also clinical picture (lesion location, efloresence, microscopic finding, type of dermatomycosis) were collected as depicted in the flowchart in the figure 1.

Specimen for direct microscopic examination was taken directly from the lesion of infected skin or hair. Specimen from skin lesion was obtained using curette or celotape band while hair specimen was taken from a location near the hair roots. The specimens were then put on top of the object glass. Specimens were then taken to the Department of Dermatology and Venerology in Dr. Hasan Sadikin General Hospital to be examined. A drop of potassium hydroxide (KOH) 10\% was applied on the specimen and a cover glass is used to cover the speciment. Fixation was performed by heating. Specimens were then inspected using light microscope. Dermatophytosis specimen would show a picture of branching hyphae with septa and arthospore. Pityriasis versicolor specimens would show short hyphae and round spora, while cutaneous candidiasis would show pseudohyphae, blastospore, and/or budding cells. Diagnostic criteria for dermatomycosis are: positive clinical pictures and direct microscopic examination.

\section{Results}

From 328 subjects, 35 of them were suspected with dermatomycosis based on physical examination. Direct microscopic examination with $\mathrm{KOH} 10 \%$ solution showed that 5 of these subjects were positively confirmed of having dermatomycosis. As such from this research the prevalence of dermatomycosis among elementary school children in the district of Jatinangor was 1.5\%.

Characteristics ofall subjects regarding their age, gender, and risk factors of dermatomycosis can be seen in table 1 . The prevalence of dermatomycosis and its characteristics can be seen on tables 2-4. In this study, from 5 students afflicted of dermatomycosis, only one less than 10 years old, and the rest were

Table 2 Prevalence of Dermatomycosis among Elementary School Children in Jatinangor on the period between September-November 2012

\begin{tabular}{lcc}
\hline \multicolumn{1}{c}{ Dermatomycosis } & n & Percentage (\%) \\
\hline Dermatomycosis (+) & 5 & 1.5 \\
Dermatomycosis (-) & 323 & 98.5 \\
Total & 328 & 100 \\
\hline
\end{tabular}


10 years old or older. This research showed that dermatomycosis attacked males more frequently with a male:female ratio was 3 : 2. Risk factors of dermatomycosis were not frequently found.

The result of this study showed that the most common dermatomycosis was pityriasis versicolor (4 cases), followed by dermatophytosis ( 1 case), and no cutaneous candidiasis case were found. There was no individual suffered from more than one type of dermatomycosis.

\section{Discussions}

The determination of the prevalence of dermatomycosis among elementary school children in this study area was conducted because this group is considered as being at risk for dermatomycosis. The risk considered is living in a humid tropical climate which can promote the growth of fungi. ${ }^{2}$ Other than that, elementary school children also have the same range of age which is between 5-14 years old. In this age range, study results showed high incidence in this specific age group, which became the basis for this study.
Prevalence of dermatomycosis among elementary school children in this study area was about $1.5 \%$. If compared to the results of Zarrin et $a l_{.}{ }^{6}$, in Iran, the prevalence that was found in this study was larger, dermatomycosis was $0.4 \%$ from 2,827 elementary school children who were examined. Several studies gained even considerably larger results, such as that found in Nigeria by Emele et al. which showed a prevalence of $10.5 \%$ from 47,723 elementary school children, and in Dar es Salaam, Tanzania, Komba et al. ${ }^{4}$ found a $20 \%$ prevalence from 420 elementary school children.

In Indonesia, studies about dermatomycosis are less common, no data about prevalence from population at risk was found. According to the research conducted by the Mycology Division of the outpatient care unit of the Dermatolo-Venereology Department of Dr. Soetomo Teaching Hospital, Surabaya ${ }^{8}$, in the year of 2003-2005, dermatomycosis was the third most prevalent dermatological diseases found after dermatitis and acne. The difference in prevalence of each research can be attributed to the difference in geographical location which also affects the growth of the

Table 3 Characteristics of Dermatomycosis among Elementary School Children in Jatinangor on the period between September-November 2012

\begin{tabular}{lccccc}
\hline & \multicolumn{5}{c}{ Patient } \\
\cline { 2 - 6 } & $\mathbf{1}$ & $\mathbf{2}$ & $\mathbf{3}$ & $\mathbf{4}$ & $\mathbf{5}$ \\
\hline Age (Years old) & 7 & 11 & 11 & 10 & 10 \\
Gender & Male & Male & Female & Male & Female \\
BMI & No & Very low & No & Obesity & No \\
Frequency of Bathing & 2 & 2 & 2 & 2 & 2 \\
Towel Usage & Shared & Shared & Not shared & Not shared & Not shared \\
Wearing of Head Cover & No & No & Yes & No & No \\
Layered Clothing & Yes & Yes & Yes & No & No \\
$\begin{array}{l}\text { Sharing of Clothing } \\
\text { Habit of Playing with }\end{array}$ & Yes & No & Yes & No & No \\
$\begin{array}{l}\text { Dirt } \\
\text { Pets }\end{array}$ & Yes & No & Yes & No & No \\
$\begin{array}{l}\text { History of Personal Skin } \\
\text { Disease }\end{array}$ & None & None & None & None & None \\
$\begin{array}{l}\text { History of Familial Skin } \\
\text { Disease }\end{array}$ & None & None & None & None & None \\
$\begin{array}{l}\text { Immunocompromised } \\
\text { Condition }\end{array}$ & None & None & None & None & None \\
$\begin{array}{l}\text { Diagnosis } \\
\text { Nityriasis }\end{array}$ & Pityriasis & Pityriasis & Pityriasis & Dermatophytosis \\
\hline
\end{tabular}


Table 4 Clinical Picture of Dermatomycosis Afflicted Elementary School Children in Jatinangor on the Period between September-November 2012

\begin{tabular}{|c|c|c|c|c|}
\hline Patient & Location of Lesion & Efloresence & $\mathbf{K O H}$ & $\begin{array}{c}\text { Type of } \\
\text { Dermatomycosis }\end{array}$ \\
\hline P-1 & Perioral & $\begin{array}{l}\text { Hypopigmentation, } \\
\text { Scales }\end{array}$ & $\begin{array}{l}\text { Short hyphae and } \\
\text { round spora }\end{array}$ & Pityriasis versicolor \\
\hline P-2 & Back & $\begin{array}{l}\text { Hyperpigmentation, } \\
\text { Scales }\end{array}$ & $\begin{array}{l}\text { Short hyphae and } \\
\text { round spora }\end{array}$ & Pityriasis versicolor \\
\hline P-3 & Back & Hypopigmentation & $\begin{array}{l}\text { Short hyphae and } \\
\text { round spora }\end{array}$ & Pityriasis versicolor \\
\hline P-4 & Right Cheek & $\begin{array}{l}\text { Hypopigmentation, } \\
\text { Scales }\end{array}$ & $\begin{array}{l}\text { Short hyphae and } \\
\text { round spora }\end{array}$ & Pityriasis versicolor \\
\hline P-5 & $\begin{array}{l}\text { Forehead (bordering } \\
\text { with scalp) }\end{array}$ & $\begin{array}{l}\text { Erythematous } \\
\text { macule, erythematous } \\
\text { papule, plaque }\end{array}$ & $\begin{array}{l}\text { Long branching } \\
\text { hyphae, have septa }\end{array}$ & $\begin{array}{l}\text { Dermatophytosis } \\
\text { (Tinea facialis) }\end{array}$ \\
\hline
\end{tabular}

fungi as pathogens (such as environmental temperature and humidity), cultural and environmental factors. Differences in the selection, collection, and number of samples in each study can also affect the difference in results. ${ }^{6}$

In this study, dermatomycosis was more prevalent in children 10 years and older. This age includes as prepuberty period. ${ }^{11}$ This is in line with the maturity of the sweat glands in the beginning of puberty which made possible a rise in the population of normal lipophilic flora such as Malassezia furfur which is the etiology of pityriasis versicolor. ${ }^{10,11}$ This is in accordance with the findings of Zarrin et al. ${ }^{6}$, in which most cases of dermatomycosis is within the range of 9-10 years old and also with the findings of Uneke et al. ${ }^{12}$, which also stated that dermatomycosis afflicted individuals within the age range of 10-13 years old.

This study found that male was at more risk of developing dermatomycosis, which is in agreement with the research of Komba et al. ${ }^{4}$, in Dar es Salaam, in which dermatomycosis was found in 50 males and 34 females. Even in the study conducted by Enemuor et al. ${ }^{13}$, in Nigeria, there was a stark difference with 129 males and 15 females were afflicted with dermatomycosis. This result may be due to much higher activity found in males rather than females. ${ }^{13}$

Dermatomycosis is a disease influenced by a humid environment, personal and environmental hygiene, contact with infection spreading agents (man, animal, and incontaminated objects), and deficient immune system. ${ }^{5} \mathrm{~A}$ humid environment, aside of being affected by climate and weather, it can be argued that it can also be created from the wearing of head cover and layered clothing. Self-hygiene in this research was determined by the frequency of bathing by the individual. Contact of disease was defined as the sharing use of towel, sharing clothing, presence of pet, and playing with soil. Pet and soil can be a source of infectious fungi which are either zoophilic or geophilic. ${ }^{5}$ Generally, the hygiene of individual afflicted with dermatomycosis in this research was considered adequate and only a few of them have risk factors.

Immunocompromised condition in this research was defined as a low immune condition of the individual attributed to immunosuppresive medications or chronic disease. Immunocompromised conditions such as diabetes mellitus patients is a predisposition factor for candida infection. ${ }^{2}$ The research showed that only $0.6 \%$ had the condition, which is in accordance to the event of dermatomycosis in this research which did not show any event of cutaneous candidiasis.

In this study, the most common type of dermatomycosis was pityriasis versicolor, and only one case of dermatophytosis was found. This result was not in accordance with the study done by Amoran et al. ${ }^{14}$, about the pediatric dermatological condition in school children of Sagamu, Nigeria, in which 159 (74.1\%) of dermatological cases of fungal infection, were dermatophytosis. Komba et $a l^{4}{ }^{4}$, in Dar es Salaam also showed less pityriasis versicolor than dermatophytosis at $36(8.6 \%)$ and $48(11.4 \%)$ from all samples in 420 students.

The result of this study was in agreement with those of Zarrin et al. ${ }^{6}$, in Iran, in which pityriasis versicolor was more prevalent than dermatophytosis. This is possible because of 
the less contact the afflicted individuals had with source of dermatophytosis infection such as pet, soil, and contacts with objects or people who have been in contact with an etiological agent. $^{5}$

There is a characteristic difference between dermatophytosis and pityriasis versicolor case. Lesion observed in dermatophytosis afflicted individual in this study was found in the border of face with scalp which was a border of the glabrous skin, a form of tinea corporis(tinea facialis).5,15 Tinea corporis is a form of dermatophytosis which can occur in all ages and in some literature, it was mentioned that tinea corporis was one of the most common dermatophytosis cases in children after tinea capitis.5,16 Tinea facialis happens more in children and often caused by anthropophilic dermatophyte which is spread all across the world, such as T. Mentagrophytes and T. Rubrum.5,15 Transmission of antropophilic dermatophyte is usually through direct contact with other infected individual or with a contaminated object.5 But, for individuals afflicted with tinea facialis found in this study, the characteristics did not show contact with either other afflicted individual or contaminated object.

Lesions on pityriasis versicolor cases have difference regarding the location and its characteristics. Location of lesion found is more in the back region, followed by perioral and buccal region. The lesions showed both hypo and hyperpigmentation type, but hypopigmentation was found more frequent. The location of pityriasis versicolor was similar with the finding of Rijal et al.17, which stated that pityriasis versicolor lesion in children was more on the faces of children. But from the characteristics of lesion, pityriasis vesiclor in these researches showed hypopigmentation type, which is in agreement with this study.17

The conclusion of this study was that dermatomycosis among elementary school children in Jatinangor in the period of September-November 2012 has low prevalence $(1.5 \%)$, affecting those in prepubescent (10 years old or more) and most commonly occur in males. The most common type of dermatomycosis in this study is pityriasis versicolor.

To know more about dermatomycosis prevalence among elementary school children in Indonesia, further studies with greater sample size will be needed. A further study to recognize risk factors is also needed with a different study design.

\section{References}

1. WHO. Epidemiology and management of common skin diseases in children in developing countries. Geneva: World Health Organization. 2005:54.

2. Havlickova B, Czaika VA, Friedrich M. Epidemiological trends in skin mycoses worldwide. Mycoses. 2008;51 Suppl 4:215.

3. Olasode OA, Otu A, Henshaw EB, Akpan N. Cutaneous Infections in Patients Presenting in a Skin Clinic in the Tropics. Int J Tropical Med. 2009;4(3):119-22

4. Komba EV, Mgonda YM. The spectrum of dermatological disorders among primary school children in Dar es Salaam. BMC Public Health. 2010;10:765.

5. Wolff K, Johnson RA, Fitzpatrick TB. Fitzpatrick's Color Atlas and Synopsis of Clinical Dermatology. 6th ed. New York: McGraw-Hill Medical; 2009

6. Zarrin M, Poosashkan M, Mahmoudabadi A, Mapar M. Prevalence of superficial fungal infection in primary School Children in Ahvaz, Iran. Maced J Med Sci. 2011;4(1):89-92

7. Emele FE, Oyeka CA. Prevalence and etiology of dermatomycoses among children in Anambra State of Nigeria. Journal of Biomedical Investigation. 2007;5(1):1-8.

8. Hidayati AN, Suyoso S, Desy Hinda P, Sandra E. Mikosis Superfisialis di Divisi Mikologi Unit Rawat Jalan Penyakit Kulit dan Kelamin RSUD Dr. Soetomo Surabaya Tahun 2003-2005. Berkala Ilmu Kesehatan Kulit \& Kelamin. 2009;21(1):1-8.

9. Kliegman R. Stanton B, Gemelll J, Schor N, Behrman R. Nelson Textbook of Pediatrics. 19th ed. Philadelphia: Elsevier; 2011

10. Brooks GF, Carroll KC, Butel JS, Morse SA. Jawetz, Melnick \& Adelberg's medical microbiology. 24th ed. New York: McGrawHill Medical; 2007.

11. Mescher A. Junqueira's Basic Histology. 12th ed. New York: McGraw-Hill Companies,Incorporated; 2009.

12. Uneke C, Ngwu B, Egemba O. Tinea capitis and pityriasis versicolor infections among school children in the South-Eastern Nigeria: the public health implications. The Internet Journal of Dermatology [Online Journal] 2006;4(2).

13. Enemuor S, Amedu A. Prevalence of superficial mycoses in primary school children in Anyigba, Kogi State, Nigeria. Afr J Microbiol Res. 2009;3(2):062-5. 
14. Amoran 0 , Runsewe-Abiodun 0 , Mautin A, Amoran I. Determinants of dermatological disorders among school children in Sagamu, Nigeria. Educ Res. 2011;2(12):1743-8.

15. Brasch J, Hipler UC. Clinical aspects of dermatophyte infections. In: Brakhage AA, Zipfel PF, editors. Human and animal relationship: the mycota VI. 2nd ed. : Verlag Berlin Heidelberg: Springer. 2008. p. $263-86$
16. Carod JF, Ratsitorahina M, Raherimandimby $\mathrm{H}$, HinckyVitratV, RavaolimalalaAndrianaja V, Contet-Audonneau N. Outbreak of Tinea capitis and corporis in a primary school in Antananarivo, Madagascar. J Infect Dev Ctries. 2011;5(10):732-6.

17. Rijal A, Agrawal S, Bhattarai S. Prevalence and clinical features of pityriasis versicolor in children. Health Renaissance. 2012;10(2):105-7. 